\title{
DIVERGENT LEGAL CONCEPTIONS OF THE STATE: IMPLICATIONS FOR GLOBAL ADMINISTRATIVE LAW
}

\author{
JANET MCLEAN*
}

\section{INTRODUCTION}

Different areas of law appear to conceive of the state in fundamentally different ways. In particular, public international law, in its twentieth century guise, has tended to conceive of the state as a unified legal person, a perpetual entity able to bind itself into the future. Domestic administrative and constitutional law in the common law tradition, by contrast, does not conceive of the state at all, but rather views the government apparatus as a series of disaggregated entities often competing with each other for power, subject to checks and balances, and enjoying a temporally contingent mandate. Indeed, in many constitutional democracies, often it is the constitution itself that comes closest to a domestic embodiment of statehood.

A central premise of this paper is that the success of the various strategies for the development of transnational systems of governance will depend on how well they integrate or assimilate these differing domestic and international legal archetypes of the state. The paper begins by suggesting different ways in which the competing conceptions have been, and can be, integrated and assimilated. British colonial law's successful integration of the international and domestic law sovereign in the office of the Crown at the point of acquiring new territory is an important historical example and is considered first. The prevalence of colonial law at earlier times of transnational government also has tended to obscure the significance of the fundamental differences between domestic and international legal conceptions as they sometimes present themselves today. A contemporary technique that has further masked these differences is dualism. The limitations of this technique, given the expansion of international rulemaking, are briefly considered.

The paper proceeds from the premise that the different techniques by which spaces for global governance can be and have been created are important for,

\footnotetext{
Copyright (C) 2005 by Janet McLean

This Article is also available at http://law.duke.edu/journals/lcp.

* Professor of Law, University of Auckland

Thanks to Benedict Kingsbury, Treasa Dunworth, Mayo Moran, Paul Rishworth, Tim Mulgan, and the participants at an Expert Workshop on International Challenges to the Australian Legal System, Canberra August 2004, and especially to the organizers Hilary Charlesworth and George Williams.
} 
but distinct from, an evaluation of the capacity for a global administrative law to operate within those spaces so created. The sites of global governance are not necessarily the sites of global administrative law. Yet how the global space is created may have an impact on which of the techniques and functions of administrative law are likely to be effective.

Domestic administrative law in the British Commonwealth tradition tends to focus on judge-made, ex post supervision of administration. ${ }^{1}$ Information disclosure regimes, access to information, ombudsmen complaint procedures, and the analysis of institutional design have only relatively recently attracted general attention among common law administrative lawyers outside of the United States. For the most part, the ex ante notice and comment rulemaking procedures that characterize U.S. administrative law have not been embraced in other common law jurisdictions, except in a piecemeal statute-specific way, and are commonly perceived as overly legalistic. ${ }^{2}$ These different techniques of domestic administrative law, then, fulfill different functions and promote different and sometimes conflicting values. Ex post judicial supervision of decisionmaking, for example, may variously fulfill the functions of centralizing control, legitimating both the decisionmaker and the decision (without necessarily imposing constraints or control), interpolating values into the decisionmaking process, enhancing rationality, or enforcing participation. Information and notice-and-comment regimes have participation as their core concerns. Not all of these techniques or functions of domestic administrative law are equally effective on their own terms, nor are they equally readily translatable to the different sites of global governance.

This paper goes on to identify how two different kinds of global space are created and to evaluate the prospects for certain functions of administrative law, as we understand it domestically, to be effective within those spaces. It identifies domestic administrative law doctrine as having the capacity to assimilate domestic and international conceptions of the state by uniting the executive in its domestic and foreign affairs personas (thus creating a space for global administrative law to operate). Within this space, domestic administrative law has developed disciplines by which it can receive and domesticate fundamental international law norms.

As much as domestic and international public law apparently share similar values, one's views of how those values ought to operate tend to be affected by one's conception of statehood. In some cases the apparent coherence between domestic and international norms-and particularly human rights norms-may prove to be illusory precisely because the domestic and international systems

1. This is reflected in the focus of DAVID DYZENHAUS, EMERGING FROM SELF-INCURRED IMMATURITY (Institute for International Law and Justice, Global Administrative Law Series, Working Paper 2005/1).

2. There are, of course, many exceptions. For example, consultation processes are commonly imposed by legislation in New Zealand; environmental and planning regimes confer broad notification and participation rights. See, e.g., Resource Management Act, 1991 R S vol 32 ss93-95 (N.Z.). 
differ fundamentally in how they conceive of the state. A norm may be understood differently as a consequence of how the state is imagined in the domestic and international spheres.

The second kind of global space on which the article briefly focuses poses greater challenges for the operation of administrative law values and functions (at least as they are understood in domestic administrative law). It identifies a further strategy for the integration and assimilation of the international and domestic conceptions of the state that creates a space for global governance by disaggregating the state into functional units (both public and private) in both the domestic and international spheres. Paradoxically, however, this very strategy for enhancing the prospects for transnational government may also hinder the applicability of administrative law techniques and values. There is no reason to suppose the problems about the reach of administrative law techniques and values encountered in the domestic context will be eliminated in the global sphere.

II

\section{DISGUISING THE DIFFERENCES BETWEEN CONCEPTIONS OF THE STATE}

The presence of a distinct legal person of the state in its external legal affairs, and the apparent absence of one in the internal governmental order, is striking and carries with it important implications. It should make us uneasy about the relationship between domestic and international public law and about the notions of sovereignty on which they depend. Yet, this striking difference in how international and domestic public lawyers imagine the state as a legal person is not obvious most of the time. This section explores the ways in which the differences in conception have traditionally been disguised and why these particular strategies are no longer as viable as they once were.

\section{A. Colonial Law}

The history of empire and colonization reminds us that the distinctions between domestic and international law conceptions of state have not always been either important or apparent. Until the twentieth century, public international law had been parsimonious about which groups could be accorded international legal personality and could thus be regarded as having the legal status of states. ${ }^{3}$ While relationships between those states belonging to the European Family of Nations were mediated by international law, it was not international but colonial law that governed most of the interactions between sovereigns and the inhabitants of the "new" territories. Relationships now governed by the law of

3. Antony Anghie, Finding the Peripheries: Sovereignty and Colonialism in Nineteenth-Century International Law, 40 HARV. INT'L L.J. 1, 1-7 (1999); SIR KENNETH ROBERTS-WRAY, COMMONWEALTH AND COLONIAL LAW (1966). The number of states has been vastly expanded in the post-colonial era. 
nations were in the seventeenth, eighteenth, and nineteenth centuries governed by, for example, English, Dutch, Belgian, or French colonial law.

A number of lessons can be learned from the British colonial experience. The British Empire was, after all, a transnational government of an earlier era. ${ }^{4}$ The merging of the international and domestic in the Colonial Crown was critical to the legal implementation of colonization. The obvious point at which the internal and external concepts of state collapsed was at the point of the initial colonial encounter itself. On acquisition or conquest of new territory, actions that began as an exercise of external foreign affairs power often simultaneously set the terms for the internal governance of that territory. The concept of the Crown enveloped any potential differences between the sovereign's foreign affairs and internal constitutional roles. External prerogative power was simultaneously constituent power.

The sacred prerogative of the Crown under British colonial law included powers to acquire territory and to constitute a local legislature. ${ }^{5}$ Promises made to the indigenous people in the process of acquiring territory, whether by way of proclamation, treaty, or charter, were (at least in earlier times) regarded by the courts as binding on the Crown in its subsequent governance of the territory. ${ }^{6}$ While it was unclear what status treaties and charters made with indigenous inhabitants would have had at international law, they were efficacious as a matter of colonial law and regarded as proof of the voluntary abandonment of the prerogative rights of the Crown. ${ }^{7}$ In the absence of treaties conferring rights

4. Executive government was not territorially defined-at least as far as the law was concerned. According to colonial law, the sovereign governed his subjects outside his territory and could, by charter, confer on them exclusive rights to trade or to settle outside territory that were enforceable at English law (The Great Case of Monopolies 36 Car. II 1684). It still was not clear as late as 1698 whether the Crown needed Parliament's agreement to confer such charters. For example, statute 9 \& 10 Gul. III c. 44, created a new East India Company. In form, the legislation did not directly threaten the Crown's prerogative. It did not directly grant an exclusive right to trade on the East India Company but instead created the corporation to whom the King was to grant Charters. This allowed the King's prerogative rights to be retained at the same time as recognizing a role for Parliament. See SIR W. W. HuNTER, A HiSTORY OF BRITISH INDIA 317-20 (1900).

The Crown was regarded in law as a single and indivisible entity throughout the Empire. The Crown, represented by a single person and single office, was sovereign in relation to the whole of the British Empire (notwithstanding the differing democratic and constitutional status of the various territories). Political practice was quite another matter. Executive power was jealously guarded as a measure of political independence in the colonies long before domestic parliaments achieved full lawmaking powers.

5. Phillips v. Eyre, 6 Eng. Rep. 1, 18 (Q.B. 1870); Campbell v. Hall (1774), 1 Cowp. 204, [15581774] All ER Rep 251, 98 ER 1045.

6. In Campbell, 1 Cowp. 204, 98 Eng. Rep. 1045, Lord Mansfield concluded that a mere proclamation could effect a binding promise. Upon winning Grenada from the French, for example, the English articles of capitulation promised the inhabitants that they should pay no higher duties than those imposed by the French King until the new King's pleasure be known. By a subsequent proclamation and letters patent the Crown stated that an assembly would be the institution to make laws for the territory and appointed a Governor to summon such assembly. Before the Governor had been dispatched from England, the King issued a further proclamation increasing the duty. Lord Mansfield held that the latter proclamation was void to the extent that it contradicted the earlier undertakings. They had binding effect within the territory.

7. Mayor of Lyons v. East India Co (1836) 1 Moo PC 175, 287. 
of British subjects on local people, for example, the subjects of a ceded or conquered territory would have been treated as aliens under British law.

The Colonial Crown was regarded in these circumstances as capable of being bound by its previous promises simultaneously as a matter of "domestic" and external or "international" law, as well as morality. Crown proclamations, at least those made upon the assumption of jurisdiction over newly "discovered" or acquired lands, were treated as having force and effect. A kind of social contract between the new sovereign and the people, on which sovereignty was conditioned, was overtly recognized in the legal analysis. The constituent aspects of the state, at least in relation to the point of its inception, so often suppressed in our modern law, were able to be recognized. In the twentieth century, judges have but rarely accorded such instruments the status of the Magna Carta or treated them as the equivalent of an entrenched provision in a constitution. $^{8}$ The farther we are in time from the initial point of acquisition, the harder it is to give effect to such undertakings in the absence of formal incorporation into a constitutional higher law document.

This distinct conception of the Crown in colonial law is not merely a historical oddity we need not trouble with today. Questions remain about the status of promises that are part of the constituent act of creating states. The New Zealand political and legal system, for example, continues to struggle with which institutions are committed by the undertakings made by Queen Victoria's representatives to Maori in the Treaty of Waitangi $1840 .{ }^{9}$ Even today, Maori appeal for redress of grievances to the Crown as if it were a unified and apolitical entity. This view, that the Crown's commitments under the Treaty of Waitangi are pre-political and constituent of the state itself, and that in fulfilling such commitments the Crown neither engages with nor is bound to engage with democratic processes, is understandable when viewed against the colonial conception of the Crown. ${ }^{10}$ This article will discuss how contemporary domestic and international courts consider constituent acts of state. The important point, for now, is to notice how such acts were regarded as a matter of colonial law.

8. See, e.g., the New Zealand case of Wi Parata v. Bishop of Wellington (1877) 3 NZ Jur (NS) SC 72,78 in which Judge Prendergast suggested that the Treaty of Waitangi between Maori and the British Crown was "a simple nullity." Contrast, R v. Secretary of State for Foreign and Commonwealth Affairs, ex parte Indian Association of Alberta, [1982] 2 All ER 118, 124 per Judge Denning citing Judge Laskin in Calder v. Attorney-General of British Columbia (1973) 34 DLR (3d) 145 at 203 suggesting that the promises by the King to the Native American peoples should be treated as "analogous to the status of the Magna Carta" and "as a fundamental document upon which any just determination of original rights rests."

9. See, e.g., Te Heu Heu Tukino v. Attorney-General [1999] 1 NZLR 98, deciding that the Treaty is binding on the Crown but not on state-owned enterprises.

10. Some Maori also argue that as a collective entity they should be viewed as an international legal person who continues to treat with the Crown. This conception of the Crown is reflected in the parliamentary practice of enacting settlements between government and particular tribes without amendment. See, e.g., Ngai Tahu Claims Settlement enacted as Ngai Tahu Claims Settlement Act 1998 No. 97 (N.Z.). 
British colonial law may in earlier centuries have created a space distinct from the domains of international and domestic law and camouflaged the differences between them. This should serve as a reminder that statehood, as it is presently understood in international law, is a relatively recent phenomenon that may not be strong enough to withstand, at least in its archetypal form, the proliferation of states over the past century. ${ }^{11}$ Archetypes do, however, matter. Many of the current legal controversies concerning indigenous peoples have as one of their causes the differences between the contemporary international law and historical, colonial law accounts of statehood.

\section{B. Contemporary Methods That Disguise the Distinction: Dualism}

The most obvious contemporary means for reconciling the distinct conceptions of the state in domestic and international law is dualism. Dualism requires that for an international agreement to have domestic legal effect, it must be incorporated into municipal law. ${ }^{12}$ In this way, English legal positivism has limited the Crown's juristic status in both the international and domestic spheres. Parliament retains its (nineteenth-century) place as the font of sovereignty. The attempts to improve parliamentary-based treaty processes can be viewed as part of this continuing dualist tradition.

While adapting and developing these strategies is an important task, they will never be a complete answer, given the expanding regulatory subject areas being confronted at an international level and the increasing degree to which power is delegated to executive bodies within treaty frameworks. Two examples from New Zealand help to illustrate this point. The Trade Marks Act $2002^{13}$ so deeply embeds the Paris or TRIPS agreements ${ }^{14}$ into the statutory framework that the legislation cannot be understood without reference to the texts of the international agreements. The Act refers to the agreements without detailing what is said in the text. Indeed, the legislation can never stand on its own because it also refers to the Paris or TRIPS agreements as "revised or amended from time to time." Even more controversial are provisions such as those contained in the Climate Change Response Act $2002^{15}$ that give effect to the Kyoto Agreement. The Act not only incorporates into New Zealand law what already has been agreed to in the Treaty process but also gives any agreements that will be entered into in the future the status of law. It incorporates by reference any decisions, rules, guidelines, measures or modifications, or agree-

11. See M. Koskenniemi, The Gentle Civilizer of Nations: The Rise and Fall of INTERNATIONAL LAW 1870-1960 (2001); Anghie supra note 3, at 1-7.

12. See, e.g., R v. Home Secretary ex parte Brind [1991] 2 WLR 588, 591 H per Lord Bridge.

13. 2002 no. 49 (N.Z.).

14. Convention for the protection of Industrial Property signed at Paris on 20 March 1883 as revised or amended from time to time and Agreement on Trade related Aspects of Intellectual Property rights set out in Annex 1C to the WTO Agreement, as revised or amended from time to time. See s 5, 2002 no. 49 (N.Z.).

15. 2002 no. 40 (N.Z.). The English text of the Protocol to the U.N. Framework Convention on Climate Change done at Kyoto on 11 December 1997 appears in Schedule 2. 
ments made under the Kyoto Protocol for the future. ${ }^{16}$ Under the Act these automatically receive the legal force of regulations.

The question of how the traditional practices of dualism can properly accommodate processes for the elaboration of treaties is inevitable. The problems of reaching agreement at the domestic level are, if anything, exacerbated in the international sphere. Unsurprisingly, this leads to general texts that require further elaboration in individual cases and further rulemaking by "executive type" processes-either through international institutions or through the cooption of national ones, or both. Many treaties explicitly set up institutions for their own elaboration-either of a judicial or quasi-judicial kind, or of a plenary character. The most interesting of these, at least to a domestic public lawyer, are those that contain provisions empowering the member states freely to amend the original treaty. Though the analogy is not completely apt, these can be likened to Henry VIII clauses in domestic public law in which Parliament by statute empowers the executive to change the statute at a later date. Some treaty arrangements require elaboration by resolution of an executive committee. These arrangements are similar to situations in domestic law in which an executive order is subject to legislative confirmation.

Domestic administrative law has taught that legislative processes cannot be used to decide everything. Administrative law is concerned (inter alia) with the implementation of general rules in particular cases and the making of more detailed rules within broad legislative frameworks. More should not be expected from democratic legislative processes at the international level than is expected at the national level.

Some would like to treat the E.U. experience of institutional dominance by bureaucratic institutions as sui generis. From an administrative lawyer's perspective, the development of strategies for the implementation or elaboration of treaty commitments demonstrates a paradox. The institutional expansion of the European Court of Justice (ECJ) and E.C. may be credited, in part, to the onerous procedures required by the Treaty of Rome before it could be amended. The expansion of ECJ jurisdiction may be traced to the requirement for unanimous agreement by member states before amendments to the original treaty could be made and to the stringent internal domestic procedures required by some member states in turn before they could agree to such changes. Unanimity of member states and internal domestic requirements of agreement (including by way of voter referendum) may have contributed to the institutional autonomy of the bureaucratic and judicial parts of the Union. ${ }^{17}$ Whether such delegations are explicit or not, systems always will find elaboration and implementation mechanisms. Either way-whether or not the substantive provisions of a Treaty are more or less "democratically mandated"-institutions for its im-

16. Section 51,2002 no. 40 (N.Z.).

17. See M. Shapiro \& A. Stone Sweet, On Law, Politics AND Judicialization 266-67 (2002) (explaining why member states never overturned the ECJ's interpretation of treaties). 
plementation and elaboration are likely to evolve. To generalize the E.U. experience may be to predict that making one part of the system more democratic, in an electoral-legislative sense, will contribute to the institutional autonomy of another.

The inherent limitations of dualism as a strategy, in these circumstances, ought to be obvious. The question then is not whether processes should be developed for the legislative, judicial, and administrative elaboration of treaties, but which processes are to be preferred and how states and citizens should be represented in such processes. The success of such processes will depend on how well the various contemporary strategies integrate or assimilate the domestic and international legal conceptions of the state.

Two possibilities for such processes are (1) the capacity for domestic administrative law to embrace international law rules and norms and (2) the prospects for an international administrative law to apply in the global spaces created by the forces of deregulation and privatization.

\section{III}

\section{THE PERMEABILITY OF DOMESTIC}

\section{ADMINISTRATIVE LAW TO INTERNATIONAL NORMS}

National courts have great potential to act as agents for the elaboration and implementation of international law norms through the doctrines of administrative law. ${ }^{18}$ Administrative law in New Zealand, Canada, and to a lesser extent, Australia, has become increasingly permeable to both constitutional and international law norms and an important means by which incorporation doctrine has been circumvented in recent years. The "hole in the donut" of executive discretion may well provide a channel for both the integration of the external state and internal executive and of international and domestic law norms.

International norms have increasingly been used to constrain and structure administrative discretion. Courts in Canada, Australia, and New Zealand, for example, have founded legal consequences on the act of ratification of the United Nations Convention on the Rights of the Child. ${ }^{19}$ The act of ratification by itself without incorporation is capable of triggering legal standards against which departures from such undertakings must be justified. ${ }^{20}$ The question of exactly what the legal consequences of ratification should be has remained a matter for domestic administrative law to decide. The cases differ as to whether ratification of the particular international obligations in individual cases can

18. Of course, administrative law also serves other instrumental and normative purposes, some of which will be discussed in a later section.

19. Tavita v. Minister of Immigration [1993] 2 N.Z.L.R. 257; Minister of State for Immigration and Ethnic Affairs v. Teoh (1995) 183 CLR 273 (Austl.); and Baker v. Canada (Minister of Citizenship and Immigration) [1999] 2 S.C.R. 817. On the latter see the book of a conference devoted to consideration of the case: THE UNITY OF PUBLIC LAW (David Dyzenhaus ed., 2004).

20. David Dyzenhaus, Murray Hunt \& Michael Taggart, The Principle of Legality in Administrative Law: Internationalisation as Constitutionalisation, 1 OXFORD U. COMMONWEALTH L.J. 5 (2001). 
give rise to a legitimate expectation, ${ }^{21}$ form the basis of a mandatory relevant consideration, ${ }^{22}$ or constitute a matter to which the decisionmaker ought to be "alert, alive, and sensitive." 23 Other possible consequences may also be available in other cases involving different international obligations. ${ }^{24}$

Both the fact and the content of the executive's international commitments contribute to the permeability of administrative law in these cases. The first element focuses on the desirability for consistency of the executive's express undertakings as a matter of administrative law. The second element focuses on the desirability of unifying the norms themselves. While in practice these two elements tend to intersect, they shall be kept separate for the purposes of this discussion.

Increasingly as a matter of domestic administrative law, executive undertakings by way of published policies and specific representations to individuals have been held by courts to give rise to legal obligations. ${ }^{25}$ Such developments contribute to enhancing the permeability of domestic administrative law to international law values and processes. Commitments made by the executive in the international sphere have at least as much, if not more, claim to legal significance as these domestic undertakings. The common administrative law motivation here is to maintain the consistency and integrity of, and the citizens' ability to rely on, executive undertakings in whichever sphere they are made. The effect, in the international law cases, is to unify the executive qua external state persona and the executive qua internal persona, with the assistance of the domestic courts.

The ideal that "[p]ublic power must ... at a minimum, exhibit some kind of fidelity to the values it has itself expressly adopted" is present in all of these cases. $^{26}$ The executive's voluntary undertaking is the focus of this strand of reasoning. In Teoh, for example, the majority was concerned that the solemn undertaking at international law should not be dismissed as "merely platitudinous or ineffectual" 27 and in Tavita as "at least partly window-dressing." 28 In a recent

21. Teoh (1995) 183 C.L.R. 273 (Austl.).

22. Tavita [1994] 2 N.Z.L.R. 257.

23. Baker [1999] 2 S.C.R. 817.

24. Claudia Geiringer, Tavita and all That: Confronting the Confusion Surrounding Unincorporated Treaties and Administrative Law, 21 NEW ZEALAND U. L. REV. 66 (2004). The interaction between the wording of the convention in the Teoh, Tavita, and Baker cases and the context of the statutory discretion (a dispensing power) makes it difficult to suggest that the Convention could act as a constraint on the scope of the power here, though one can think of other cases in which the wording would not be so constraining. Indeed, the UNCRC indicates that the interests of the child are a matter to be weighed as "a [primary] consideration" (Article 3).

25. See, e.g., SOREN J. SCHONBERG, Legitimate ExpeCtations in Administrative Law (2000); ROBERT THOMAS, LEgITIMATE EXPECTATIONS AND PROPORTIONALITY IN ADMINISTRATIVE LAW (2000).

26. Mayo Moran, Authority, Influence and Persuasion: Baker, Charter Values and the Puzzle of Method, in THE UNITY OF PUBLIC LAw 389, 404 (David Dyzenhaus ed., 2004).

27. Id. at 402, quoting Minister of State for Immigration and Ethnic Affairs v. Teoh (1995) 183 C.L.R. 273, 291 (Austl.) per Mason CJ and Deane J.

28. Tavita v. Minister of Immigration [1994] 2 N.Z.L.R. 257, 266; Moran, supra note 26 at 402. 
New Zealand decision, Justice Glazebrook also emphasized the desirability for consistency within the executive's publicly addressed values. She was concerned that the New Zealand refugee operational instructions referred to some, but not all, of the UNHCR guidelines. ${ }^{29}$ The potential impropriety here was in the executive "picking and choosing" between its international commitmentsat least without good reason. ${ }^{30}$

Focusing on the fact of the commitment itself may also contribute to a greater definition of institutional hierarchies at the international level. The fact of the commitment sometimes leads directly to questions about the quality of the commitment. New Zealand judicial decisions, for example, have begun more finely to differentiate between international law texts. ${ }^{31}$ In Refugee Council v. Attorney-General, Justice McGrath was careful to acknowledge that the "executive guidelines" issued by the U.N. High Commissioner for Refugees (a non-elected U.N. official), while helpful in interpreting the Convention, did not enjoy the same status as resolutions of the UNHCR executive committee, an assembly of state representatives. ${ }^{32}$ This may be regarded as an early attempt to insinuate some kind of institutional separation of powers into the international sphere. The international bodies may, however, be even more difficult to classify in domestic constitutional law separation of powers terms than Justice McGrath acknowledges. The Executive Committee is established by the High Commissioner's Office, does not include all parties to the Convention, and currently includes four members who are not parties to the Convention. ${ }^{33}$ This is, at least, a start. As a general matter, the more seriously international commitments are taken by domestic administrative courts, the greater the incentive for states to be careful and disciplined about the content of decisions and the design of international decisionmaking processes. These developments may, however, also increase the difficulties of reaching agreement in the international sphere.

Viewed from the perspective of how successfully they rationalize external and domestic conceptions of the state, cases such as Teoh (Australia), Tavita (New Zealand), and Baker (Canada) take on a different significance from that usually ascribed them. Each of these cases was triggered by the executive's undertaking (in its international persona) obligations under the U.N. Convention on the Rights of the Child. In each case the commitment affected the executive's exercise of its discretion in its domestic persona. There was no direct clash with Parliament here-in each case Parliament had delegated to the executive the decision about what "humanitarian" factors would include. The

29. Refugee Council v. Attorney-General [2003] 2 N.Z.L.R. 577, 650 per Glazebrook J.

30. Justice Glazebrook treated the UNHCR guidelines as having the same status as judicial decisions from other jurisdictions. Refugee Council, 650.

31. Treasa Dunworth, Public International Law, New ZeALAND L. Rev. 411, 415-18 (2004).

32. [2003] 2 N.Z.L.R. 577, 612, per McGrath J.

33. The Committee currently has 66 members including India, Pakistan, Lebanon, and Thailand who are not parties to the Convention: http://www.unhcr.ch/cgi-bin/texis/vtx/excom. (My thanks to Treasa Dunworth for assistance on this point). 
judges were being asked to give effect to a general norm (otherwise unelaborated) in an international treaty when interpreting a general norm (otherwise unelaborated) in a legislative provision.

None of the above arguments necessarily depends on the content of the international agreement-though in practice the content has been an important factor in determining the proper weight to be given those agreements in the administrative decision itself. The second set of arguments focuses not so much on the fact of the undertaking, but on the fundamental nature of its content. The motivation here is to use administrative law to unify fundamental constitutional, administrative, and international law norms. According to this line of reasoning, the fundamental content of the undertaking is the source of the commitment. David Dyzenhaus sums up this approach: "Baker seems best understood as a decision that conceives of public law as based in a set of fundamental values, which are expressed-sometimes in different ways-in administrative law, in constitutional law and in international law." 34

One's evaluation of the strength of such a claim will depend on the position one takes in relation to the domestic administrative law controversy about whence administrative law derives its values. ${ }^{35}$ Are judges in administrative law cases acting as agents for Parliament and enforcing Parliament's intent and values, as the traditional view tends to portray them $?^{36}$ Or is Parliament presumed to legislate against a "rule of law" floor of fundamental values as Lord Steyn has suggested when applying the "principle of legality" in administrative law cases ? $^{37}$ Or, indeed, are the values of administrative law freestanding and derived from the common law itself, as Lord Cooke has articulated? ${ }^{38}$ The declining dominance of the first of these approaches and the ascendance of the latter two-sometimes both embraced by the "principle of legality"-has increased the permeability of administrative law to arguments about fundamental norms. By this, the courts have been able simultaneously to domesticate international humanitarian values and to seek external validation of the content of domestic humanitarian norms. International law need not be the source of a norm's au-

34. The Unity of Public LAW 1 (David Dyzenhaus ed., 2004).

35. This is not a controversy triggered exclusively by the question of what role international treaty law should play. The changing internal organization of government, privatization, outsourcing, and new methods of regulation mean that this question matters in other contexts as well-in order to apply administrative law doctrines to entities that are not based on statute but are nevertheless sufficiently "public." See, e.g., R v. Panel of TakeOvers and Mergers, ex parte Datafin plc [1987] 1 QB 815, 848.

36. Richard Stewart's transmission belt theory still retains its adherents in the British Commonwealth. See Richard B. Stewart, The Reformation of American Administrative Law, 88 HARV. L. REV. 1669, 1671-76 (1975).

37. Lord Steyn describes the "principle of legality" in these terms: "In the absence of contrary indications it must be presumed that Parliament entrusted the wide power to make decisions [to the Home Secretary] on the supposition that the Home Secretary would not act contrary to such a fundamental principle of our law." R v. Secretary of State for the Home Department, ex parte Pierson [1998] 1 AC $539,590$.

38. For Lord Cooke of Thorndon the "common law by itself is being recognised as a sufficient source of the fundamental right": R v. Secretary of State for the Home Department, ex parte Daly [2001] UKHL 26, II 30-31. 
thority, but rather evidence of the norm itself. The methodology is normreinforcing. Audrey Macklin describes the process (again from a Canadian perspective): "When immigration lawyers invoke international law in aid of a Charter challenge, they call on the cosmopolitan antecedents of the Charter. When they invoke international law directly in aid of statutory interpretation, they encourage the internalisation of universal normative commitments within the national legal frame." ${ }^{39}$

Developments in administrative law in the British Commonwealth have enhanced its permeability to international norms. Administrative law's interest in maintaining the consistency and integrity of executive undertakings in whichever sphere they are made, combined with its search for unified fundamental values, makes it more likely to be influenced by international law processes and norms. There is a coincidence of common law and international law values and the permeability of administrative law to both.

\section{IV}

\section{THE LIMITS OF COORDINATING NORMS}

While administrative, constitutional, and international law norms appear to cohere, sometimes significant obstacles impede the translation of these norms across the conceptual divide between domestic and international spheres. The apparent or potential coherence between international and domestic constitutional norms sometimes unravels exactly because of the different conceptions of state operating in domestic and public international law. The constituent elements of statehood tend to be even more suppressed in international law than in domestic constitutional law.

\section{A. Constitutions as Constituent Acts}

A Canadian example may help to make the point. Canada explicitly has incorporated the norms contained in the International Covenant on Civil and Political Rights in its Charter of Rights and Freedoms. Both texts guarantee equal protection of the law and freedom of conscience and religion (among other things). ${ }^{40}$ Domestic and international courts have been asked on a number of occasions to determine whether such human rights guarantees clash with other constitutional commitments. ${ }^{41}$ In these cases, the differences between international and domestic conceptions of state can be material to the result.

39. Audrey Macklin, The State of Law's Borders and the Law of State's Borders, in THE UNITY OF PUBLIC LAW 173, 175 (David Dyzenhaus ed., 2004) (describing the process from a Canadian perspective). We should notice, however, that the Canadian Charter does not protect the rights of children but the Supreme Court nevertheless found a way to give effect to children's interests in Baker.

40. Articles 2, 14, and 18 ICCPR and s15 and s2 CCRF respectively.

41. E.g., Adler v. Ontario [1996] 3 S.C.R. 609; Public School Boards Association v. Alberta (A-G) [2000] 2 SCC 410; Waldman v. Canada, 7 IHRR 368 (2000); Re: An Act to Amend the Education Act [1987] 1 SCR 1148 [Bill 30 Act] (Can.). 
The 1867 Constitution created a United Canada and implemented and incorporated important compacts made at the time of Confederation. The constitutional text documents the promises that were constitutive of nationhood (including, inter alia, special guarantees to the indigenous peoples). Importantly, for present purposes, it guaranteed certain rights and privileges to the Roman Catholic minority in Ontario and reciprocal rights and privileges to the Protestant minority in Quebec. Section 93 granted each province exclusive jurisdiction to enact laws regarding education. In Ontario, these powers were exercised for the public funding of Roman Catholic elementary schools at the same level as public secular schools. In the 1980s legislation was proposed in Ontario that sought to extend the provision of publicly funded Roman Catholic schools to include secondary as well as primary education. This was because, when the constitutional arrangements first were made, most people received only primary education and the changes were necessary to fulfill the spirit and intention of the agreement. In Ontario, Roman Catholic Schools were the only religious schools entitled to the same public funding as public secular schools. A legal challenge was brought on the basis that these provisions discriminated against non-Roman Catholic parents who wished their children to have a religious education. The question for the Canadian Supreme Court in Re: An Act to Amend the Education Act was whether the adoption of the Charter could change the Confederation bargain. ${ }^{42}$

Section 29 of the Charter itself seems to have anticipated exactly this kind of challenge: "Nothing in this Charter abrogates or derogates from any rights or privileges guaranteed by or under the Constitution of Canada in respect of denominational, separate or dissentient schools." The Supreme Court of Canada upheld the proposed legislation but made clear it did not need to rely on Section 29 of the Charter in order to find the Constitution prevailed over the Charter of Rights and Freedoms. According to Justice Wilson, "Their protection from Charter review lies not in the guaranteed nature of the rights and privileges conferred by the legislation but in the guaranteed nature of the province's plenary power to enact that legislation." ${ }^{43}$ She had stated earlier, "It was never intended ... that the Charter could be used to invalidate other provisions of the Constitution, particularly a provision such as s. 93 which represented a fundamental part of the Confederation compromise." ${ }^{44}$

Justice Estey concurred, saying, "Section 93 is a fundamental constitutional provision because it is a part of the pattern of the sharing of sovereign power between the two plenary authorities created at Confederation." 45 He likened it to the special provisions made for the preservation of Indian lands at confederation.

42. Re: An Act to Amend the Education Act [1987]1 S.C.R. 1148 (Can.).

43. Id. at 1198 .

44. Id. at $1197-98$.

45. Id. at 1206 . 
The Supreme Court considered Section 93 fundamentally constitutive of Canada as a nation. Without it, there would not be a nation. It could not, therefore, be subordinated to the Charter's equality protections. To paraphrase the Supreme Court, the (internal) nation state, and the original compact under which it was formed, came first. One could not use the Charter of Rights to undermine the very nature of the nation state itself as originally founded. There is recognition here of the historical and the constitutive elements of statehood on which other rights may depend. ${ }^{46}$ The Constitution, in this case, is symbolic of a shared history and values and represents an idea of nationhood. It is an attempt to forge coherence between nationhood as a political, social, and legal phenomenon. As such, it does not serve merely instrumental ends. As Justice Robert Jackson observed in another context, the Constitution is not a suicide pact. $^{47}$

In 1999, a Jewish parent challenged the Ontario education funding provisions before the Human Rights Committee under the Optional Protocol to the ICCPR. ${ }^{48}$ The challenge again alleged the provisions were discriminatory and denied equal protection of the law to parents wishing to send their children to other religious schools. This time the government was not prepared to concede (as it had earlier) that but for the provisions of the 1867 Constitution, the education legislation breached the Charter. The State Party relied on the arguments of Justice Wilson in the Supreme Court and explained that

\section{without the protection of the rights of the Roman Catholic minority, the founding of Canada would not have been possible and that the separate school system remained a controversial issue, at times endangering the national unity in Canada. The State Party explains that the funding is seen by the Roman Catholic community as the cor- rection of an historical wrong. ${ }^{49}$}

The State Party added that undoing the bargain made at Confederation would lead to outrage and economic turmoil. The Human Rights Committee made short work of these arguments: "The Committee begins by noting that the fact that a distinction is enshrined in the Constitution does not render it reasonable and objective." ${ }^{50}$

The material before it did not show that Roman Catholics were now in a disadvantaged position compared to the Jewish Community. Canada's own fundamental commitments, including the pre-conditions of its founding, were treated as irrelevant. The Committee appeared to assume that an individual's

46. Though it is latent in the reasoning, some calculation of the risk of Quebec succession may have been operating.

47. See Terminiello v. City of Chicago, 337 U.S. 1, 37 (1949) (Jackson, J., dissenting), cited in MARTIN LOUghlin, THE IDEA OF PUBLIC LAW 91 (2003).

48. Waldman v. Ontario Human Rights Committee 67th Session 1999. CCPR/C/67/D/694/1996. Notice that subsequently in Ontario English Catholic Teachers' Ass'n v. Ontario [2001] 1 S.C.R. 470, 494, 510, Justice Iacobucci described Section 93 as animated by principles of "religious freedom and equitable treatment" and as guaranteeing similar rights to those protected by Section 23 of the Charter.

49. Id. at $\mathbb{9} 8.3$.

50. Id. at $\mathbb{I} 10.4$. 
right to be free from discrimination is not preconditioned by the existence of a state, even if the state is the unit on which international law depends for the enforcement of such rights. A finding of discrimination does not depend on the nature of the state or its constituent elements. The only realm for shared values is the international community itself.

How instead does the Human Rights Committee, working from within our archetypal version of the state tradition of international law, conceive of the state? One reading of the decision would suggest that in order to preserve the unified permanence central to the idea of the state at international law, it is necessary for a state to be conceived as an empty, abstract, and ahistorical concept. Alternatively, one could locate this decision within a particular historical frame or system of shared values-that is the post-World War II Human Rights system.

Despite the seeming agreement about substantive human rights values in these cases, one's conception of the state is clearly crucial. Higher law constitutions do not serve only instrumental ends. They also express shared values and come close to a domestic embodiment of statehood.

\section{B. A Hybrid Version of Statehood}

Perhaps unsurprisingly, Europe seems to offer a hybridized version of the state in the human rights context. In the case of Refah Partisi v. Turkey, ${ }^{51}$ the Grand Chamber of the European Court of Human Rights acknowledged democracy as the relevant constituent element of statehood. The case involved a human rights challenge to the decision of the Turkish Constitutional Court to have the Refah political party dissolved on the basis that it was a "centre" of activities contrary to the principles of secularism. The Refah party, among other things, supported a system based on sharia law. The Grand Chamber reiterated its view that democracy is a fundamental feature of the "European public order." 52 It considered that that "there could be no democracy without pluralism" ${ }^{53}$ and viewed the state's role as the "neutral and impartial organizer of the exercise of various religions, faiths, and beliefs." that the freedoms guaranteed in the convention "cannot deprive the authorities of a State in which an association, through its activities, jeopardizes that State's institutions, of the right to protect those institutions." 55 Human rights protection then, is subject to the state's ability to survive as a democratic institution. Some compromise between defending democratic society and individual rights

51. Case of Refah Partisi (The Welfare Party) and Others v. Turkey, European Court of Human Rights Grand Chamber, hearing 19 June 2002, Application numbers 41340/98, 41342/98, and 41344/98.

52. Id. at para 86 .

53. Id. at para 89 .

54. Id. at para 91 .

55. Id. at para 96 . 
is inherent: "no[ ]one must be authorized to rely on the conventions provisions in order to weaken or destroy the ideals or values of a democratic society." 56

The argument that a democratic system is entitled to defend itself against political movements that seek to destroy it (described in the tribunal below as "militant democracy" ${ }^{57}$ ) is at odds with "pure" international legal conceptions of state. ${ }^{58}$ International law does not precondition whether a state exists on whether it is democratically ordered. International law, moreover, appears to exhibit little interest in a state's ability to survive in a particular constitutional form-as was demonstrated in the Waldman v. Ontario decision of the Human Rights Committee.

The differences of approach between the Canadian and Turkish cases might be explained on the basis that the recent history, size, and success of the Refah Party, and Turkey's role as a model of a secular Islamic state made the threats to the state's very existence more real in the latter case. However, at least in the Tribunal below, the Court went further and referred explicitly to the European experience of the use by totalitarian movements of democratic processes to do away with democracy. It presented the German and Italian Constitutions as positive examples of the principle that to outlaw certain political movements is acceptable, even when there is no immediate threat. ${ }^{59}$

The better view is that the approach taken to statehood by the Grand Chamber in Refah Partisi is quite distinct from the approach taken by the $\mathrm{Hu}$ man Rights Committee in Waldman v. Ontario. The Grand Chamber portrayed Europe as a community of shared values and shared history-for which secularism and democracy are central principles. The European Court conceived of rights from within a community of shared values among individual states: a kind of hybridized version of statehood, situated between the domestic and international legal conceptions, is operating here.

The purpose of this part of the paper is not directly to raise large questions about cultural relativism or the universalism of human rights but rather to emphasize how important one's conception of the state is to the analysis of the content of fundamental norms. ${ }^{60}$ The tension between how international law, domestic law, and the emerging law of Europe paradigmatically conceives of the state is all the more important, given that international law traditionally

56. Id. at para 99 .

57. Refah Partisi (The Welfare Party) and Others v. Turkey, Third Section Judgment of 31 July 2001, at para 62 .

58. Of course there are more nuanced versions within the international law tradition. See, e.g., M KoskenNiEMI, The Gentle CiVILIZER OF NATIONS: THE Rise AND FALL OF INTERNATIONAL LAW 205-06 (2001).

59. Refah Partisi (The Welfare Party) and Others v. Turkey, Third Section Judgment of 31 July 2001, at para 62.

60. Another example of when the difference in domestic and international conceptions of the state matters is when the fragmented parts of the state are unified for the purpose of bringing a human rights claim but a government entity might itself wish to bring an administrative law challenge against another part of the state on the basis that it had overreached its powers. 
frames the state as the primary enforcer of rights. The state may not be prior to the law, and yet, enforcement of the law depends on the state for international law purposes. This is a very unstable framework.

How courts conceive of their role as elaborator and implementer of humanitarian norms may differ depending on whether they are operating within an international or domestic model of the state. The idea of unified norms always will be moderated through a particular conception of the state. Notwithstanding the permeability of the domestic and international systems to shared fundamental norms, difficult questions of translation sometimes will remain. ${ }^{61}$

Nonetheless, the technique of creating global space by domestic courts enforcing the normative commitments of states in both their domestic and international personas invites possibilities for a global administrative law. In that sense it is a technique to engage national actors (judges) in the ex post administration of commitments made under treaty regimes. How thoroughgoing it will be will depend on how much the substantive content of the commitment matters in addition to the fact of the commitment itself. ${ }^{62}$ The impact of this technique on the content of and broader participation in those treaty regimes is more uncertain and indirect. ${ }^{63}$ That may depend on the ability of judges to create their own coordinated networks and on the feedback loops that can be established between judicial communities and the other actors involved in treaty making and elaboration. In New Zealand and Australia, these developments have resulted in calls for greater transparency of treaty making processes as a matter of both domestic and international law. Responses to such pressures have been limited.

So far only the individual in her role as enforcer of pre-agreed commitments at both the international and domestic levels has been considered. These examples engage with familiar actors and processes that both international and domestic lawyers would recognize as "governmental." The next example of the creation of global space takes one to more unfamiliar territory.

\section{$\mathrm{V}$ \\ PERMEABILITY OF PUBLIC-PRIVATE \\ InSTITUTIONS TO ADMINISTRATIVE LAW VALUES: A BRIEF SKETCH}

There is of course, a range of techniques for global governance, as Kingsbury, Krisch, and Stewart have identified. ${ }^{64}$ Two of the ideal types they describe

61. Neil Walker, Postnational Constitutionalism and the Problem of Translation, in EUROPEAN Constitutionalism BeYOND the State 27-54 (J. H. H. Weiler \& Marlene Wind eds., 2003).

62. This is a question that David Dyzenhaus addresses in THE RULE OF (ADMINISTRATIVE) LAW IN INTERNATIONAL LAW (Institute for International Law and Justice, Working Paper 2005/1, Global Administrative Law Series).

63. In terms of Kingsbury, Krisch, and Stewart's ideal types it is an example of distributed administration and may also indirectly give rise to collective action by government officials. See Benedict Kingsbury, Nico Krisch, \& Richard B. Stewart, The Emergence of Global Administrative Law, 68 L. \& CONTEMP. PROBS. 15 (Summer/Autumn 2005).

64. Kingsbury et al., supra note 63 . 
are particularly problematic for the operation of a global administrative law: administration by hybrid intergovernmental-private arrangements, and administration by private institutions with regulatory functions. As before, rather than identify the technique for creating space for global governance as necessarily the same as identifying the site for global administrative law, this paper evaluates which of the functions and techniques of administrative law earlier identified are likely to be effective, given the technique by which the global space has been created.

An important strategy that facilitates the integration of domestic and international conception of the state has been to disaggregate the state within both spheres into functional units and to divest some of those functions to private entities or public-private hybrid entities. ${ }^{65}$ This particular strategy for the creation of global space may, however, pose the largest challenge for the application of administrative law values and techniques. Indeed, the risk is that to suggest administrative law operates in such a space may be merely to invoke administrative law's legitimacy conferring function without much more.

This process began domestically with the functional reorganization of the institutions of domestic government across most of the OECD, the fragmentation and outsourcing of formerly governmental activities, and the "corporatization" or divestment of formerly public utilities and other "commercial" activities. Simultaneously, these are the very processes that have facilitated the increased reach of transnational corporations, the development of networks and epistemic communities, and, in short, enhanced the prospects for transnational forms of government. Transnational governance would not be possible if it were not for the functional reorganization of the domestic state. The labels "domestic" and "international" are no longer apt. "Government" has been replaced by the deliberately ambiguous word "governance."

Given that the reorganization of the state into functional units and subsequent divestment of "public" functions to private or hybrid entities began as a domestic phenomenon, much can be learned from the response of domestic administrative law to the challenges these developments have posed. That is not to identify the "problem" as being that such global spaces cannot be reached by domestic administrative law, but rather to question whether administrative law, as we know or are able to imagine it, has or will have the capacity to respond. The focus of the critique is not so much the global nature of the administrative law project but on the nature and content of administrative law itself.

Because all administrative law is quite sector-specific, it is important to be as specific as possible in terms of examples. The first is the domestic example of the divestment of direct government ownership and control of utilities within New Zealand. Some utilities were completely privatized (many being trans-

65. See, e.g., the divestment of formerly public owned and operated utilities in the U.K., Australia, Canada, and New Zealand. 
ferred to transnational corporations) and thus put beyond the reach of domestic administrative law. Most were, at least for a time, transferred to hybrid publicprivate bodies. The effect was that when politically unpopular decisions needed to be made, government was able to distance itself from such decisionmaking and to attribute unpopular decisions to separate entities invoking commercial imperatives. However, when government really did want to intervene (this time invoking political imperatives), for example, to repudiate logging contracts for scarce native timber, it was able to do so without administrative law constraints or ordinary contractual consequences. ${ }^{66}$ Locating power and accountability within this institutional form has proved difficult in the extreme.

And yet the problem has not been that administrative law did not reach such bodies. Indeed there has been a series of cases in which claimants sought to establish whether the ex post constraints of judicial review would apply in the hybrid public-private setting. After a judicial tousle, the Privy Council reversed the Court of Appeal and found that such bodies were subject to the disciplines of judicial review. ${ }^{67}$ In acknowledgement of the commercial context, however, it made clear it would intervene only in the most limited and non-commercial settings and only in circumstances in which the most extreme abuses of power had occurred. For all practical purposes, the limited circumstances under which such bodies could be restrained rendered judicial control illusory. No further "successful" challenges have been brought.

What of the other devices of administrative law? Fierce debates have taken place on the question whether the public should have access to the information held by these hybrid bodies. A Parliamentary select committee was successful in forestalling their removal from the coverage of the access to information regime under the Official Information Act 1982. In practice, however, much of the content of such information has been withheld because disclosure would adversely affect the commercial interests of such bodies. It may be that the application of these various administrative law mechanisms lends legitimacy but not much else to the governance of such bodies.

The British experience of applying administrative law disciplines to private entities that exercise regulatory functions is potentially even more instructive. The leading case of $R v$. Panel of Take-Overs and Mergers, ex parte Datafin plc ${ }^{68}$ involved an attempt to impugn a decision of the Panel of Mergers and Takeovers ex post because it had misapplied its own rules when approving a merger. The Panel is a private entity without "visible means of legal support" whose members are important players in the London financial markets. After much judicial exegesis, the Court concluded that the Panel was subject to the disci-

66. See also Janet McLean, Government to State: Globalization, Regulation, and Governments as Legal Persons 10 InD. J. GloBAL LEGAL STUD. 173, 186-88 (2003).

67. Mercury Energy v. Electricity Corporation of New Zealand [1994] 1 WLR 521 [PC] reversing Auckland Electric Power Board v. Electricity Corporation of New Zealand [1994] 1 N.Z.L.R. 551, 559 [CA].

68. [1987] 1 QB 815. 
plines and constraints of judicial review. However, Sir John Donaldson MR added that intervention in the work of such a body should be restricted to allowing prospective declarations concerning the meaning of the Panel's rules (rules incidentally that the Panel was able to make and change without notice or comment). ${ }^{69}$ There was no question of the court's intervening to unravel decisions already made. To allow more by way of potential judicial intervention would have undermined the very reasons for reposing such decisions in the Panel in the first place. Timely, expeditious, market informed, and expert decisionmaking would be undermined by anything more by way of administrative law constraints. Again, the main function of administrative law here seems to be to legitimate as "governance" the functions of the Panel.

These examples raise a number of questions about how administrative law will operate in relation to the global versions of similar entities. A central question will be this: Why was the mode of governance selected in the first place, and how much will that choice of instrument or institution be undermined by the constraints and disciplines of administrative law? Institutional choices themselves convey and commit to particular norms of decisionmaking.

It also will be important to identify the kinds of claims to expertise that are operating in a particular institutional setting. Are the claims to "expertise" also claims to information neither shared nor able to be shared with the general public, governments, or courts? If so, the techniques of administrative law are likely to have a limited impact. Expert institutions often are regarded as avoiding the worst kinds of political behavior and as bringing both technical expertise and deliberative processes to the resolution of problems. But, as in the domestic system, the very qualities that make the use of bureaucratic institutions attractive are also the factors that present the greatest challenges.

It may well be that, to paraphrase Eyal Benvenisti, ${ }^{70}$ administrative law accurately reflects the balance of power in any given system. That is not necessarily to derogate from the central thesis that the ways global space is created are important to if distinct from the application of administrative law within those spaces. Indeed it may be argued that certain power dynamics further the creation of particular global spaces in the first instance.

Administrative law is facing fundamental challenges to its relevance and effectiveness in the domestic sphere. These challenges have their source in some of the central forces for the creation of transnational government itself. The challenges for administrative law will be even greater in these new international and transnational regulatory spheres.

69. Id. at $842 \mathrm{D}$.

70. Eyal Benvenisti, The Interplay Between Actors as a Determinant of the Evolution of Administrative Law in International Institutions, 68 L. \& CONTEMP. PROBS. 319 (Summer/Autumn 2005). 


\section{VI \\ CONCLUSION}

This paper posits that there are radically different conceptions of the state at international and domestic law. Colonial law and dualism have, for a time, disguised these differences. The strategies for transnational government most likely to be successful are those that integrate the state in its international and domestic personas. One such strategy is the use of domestic administrative and constitutional law as a channel for fundamental norms. However, in some cases, even this strategy will have to confront how the constituent elements of the state differ under these competing conceptions. Further, and paradoxically, the paper suggests that some of the very strategies enhancing the prospects for transnational government may also threaten the applicability of administrative law values at both the domestic and international levels. 